\title{
Processing of nettle (Girardinia diversifolia) in the units of Uttarakhand
}

\author{
NEHA GARG, KANWALJIT KAUR BRAR AND HARINDER KAUR SAGGU
}

Received: 17.07.2017; Revised: 08.11.2017; Accepted: 23.11.2017

See end of the paper for authors' affiliations

\section{NEHA GARG}

Department of Apparel and Textile Science, College of Home Science,

Punjab Agricultural University, LUDHIANA (PUNJAB) INDIA
ABSTRACT : Sixteen nettle units established in Chamoli and Uttarkashi districts of Uttarakhand by Uttarakhand Bamboo Fibre Development Board were surveyed to document the production processes of nettle textiles. There were five fibre processing units and three spinning units with total strength of 310 workers. Nettle plants were collected from hilly areas by workers without paying any cost to the land owners. Nettle stalks were subjected to running water retting, beating and washing, bleaching with kaoline paste followed by carding and spinning. From one kilogram of nettle bark $400 \mathrm{~g}$ fibres could be extracted. Ultimately $300 \mathrm{~g}$ nettle yarn could be obtained from one kilogram nettle bark. Opening of nettle enterprise holts a promising opportunity for the economic upliftment of rural people.

KEY WORDS: Nettle, Technical process, Employees

- HOW TO CITE THIS PAPER : Garg, Neha, Brar, Kanwaljit Kaur and Saggu, Harinder Kaur (2017). Processing of nettle (Girardinia diversifolia) in the units of Uttarakhand. Asian J. Home Sci., 12 (2) : 602608, DOI: 10.15740/HAS/AJHS/12.2/602-608. 